exists, or which I fancy to exist, between these small genera of Glyphipterygide and the Elachistade of Mr. Stainton's classification. I can not now refer to the place where I have alluded to the subject, nor am I altogether certain that I have published the observations which then suggested themselves on this subject, as at that time I only knew the Glyphipterygida through the writings of other Entomologists. But it certainly seemed to me that the larvæ of the above-mentioned genera of small species being unknown, there was nothing in the structure of the imago to exclude them from the Elachistada, though the larger genera, Ascalepia, Glyphipteryx, etc., were allied sufficiently nearly to the Gelechide. But such species as Aichmia dentella and Lithariapteryx abronicella unite these small genera and Glyphipteryx, so that they cannot be placed in separate families, though the apodal larvæ of Antispila, Heliozella, etc., do not offer any strong affinities with either Glyphiptcrygida or Elachistade. While, therefore, it is true that these small genera can not be separated from Glyphipteryx and placed in a different family because of being so connected, nevertheless, taken by themselves, in the imago, they still seem to me to show strong affinities with the Elachistada; and, indeed, the older Entomologists placed the European species of Antispila in the genus Elachista. I) the Glyphipicrygida afford a passage from the Gelechide to the Elachistade?

\title{
DESCRIPTION OF A NEW TEXAN ANISOTA.
}

BY LEON F. HARVEY, M. D., BUFFALO, N. Y.

The following species, new to the fauna of the United States, have been collected by Mr. L. Heiligbrodt, in Bastrop Co., Texas, and the types are contained in the beautiful collection of my friend, Mr. Otto Meske, in Albany.

Anisota Heiligbrodti, n. s.

5.9 . The antennæ of the male are broadly bipectinate, except at the tips; those of the female are simple. This species differs from its allies by its purely gray color and by the fore wings being covered by two nar- 
row blackish lines. The first of these is sub-basal, irregularly sinuous, produced on the disc; the second is regularly scalloped, interspaceally waved, and runs from apical third to internal margin. The wide median space has a more purely whitish ground, while the wing everywhere is thickly dusted with dusky cells. The usual discal mark consists of two superposed white spots duskily ringed. Hind wings of the same gray with the disc bright rose color, enclosing a large round black discal spot and outwardly limited by a faint mesial band visible towards anal margin. Beneath of the same gray, with the round black discal spots repeated on both wings; the primaries alone are rose color at base, and there is a trace of a common extra-mesial band. Body gray with the sides of the abdomen tinged with roseate.

Expanse, \& 2 t/8 inch.; \& 3 inch.

Anisota Heiligbrodti, which is named for its discoverer, approaches certain southern species in form, which have been referred by Dr. Boisduval to Adelocephala.

\section{NEW SPECIES OF ORTHOPTERA.}

BY G. M. DODGE, GLENCOE, DODGE CO., NEBRASKA.

Caloptenus angustipennis, $n$. sp.

General color light brown. Upper part of pronotum and hind femora with a reddish tinge. Face sometimes mottled. Antennæ light brown infuscated apically. The usual black band behind the eye broad and distinct, and reaching last division of pronotum, bounded below by a narrower white stripe. A broad white stripe from base of elytra connects with a white stripe at insertion of posterior femora, forming a right angle. Outside of hind femora is crossed by two indistinct dusky bands that extend upon upper edge. Lower sulcation reddish. Knees black. Hind tibiæ blue. Elytra light brown with very small black spots in the disk.

Frontal costa depressed at ocellus. Head but slightly elevated above pronotum. Foveola of vertex scarcely depressed. Carinæ of pronotum nearly obsolete; the median cut by three transverse incisions. Hind lobe of pronotum slightly rugulose. Elytra extending beyond abdomen, un- 